\title{
THE STATESMEN OF KARAKALPAKSTAN (in 1950-1990)
}

\author{
Ibragimov B.
}

Assistant Lecturer, Department Of Uzbekistan And Karakalpakstan History, Karakalpak State University

\section{ABSTRACT}

The article describes the role of the statesmen of Karakalpakstan in the second half of the XX century in the social and political life of society. Based on the mars of political views, the main changes in various spheres of the economic life of Karakalpakstan.

KEYWORDS: - Memoirs, Karakalpakstan, national economy, railway, construction, cotton growing, rice growing

\section{INTRODUCTION}

The socio-political situation after the Second World War is well conveyed in the memoirs of NuriddinMukhitdinov: "Astronomical figures measured material losses, people's exhaustion from malnutrition, difficult living conditions, housing, communal conditions, long and exorbitant physical and mental stress affected. It was difficult to measure the enormous damage in the moral condition".[4,p.44]

It was difficult for the country's economy to recover, a peaceful life was difficult to establish, something was constantly lacking. The logic of "push and do" worked flawlessly, the temptation of a "simple solution" led to its approval as the only possible one and, as a result, to monopolization of trends in science, culture and social life in general.

The memoirists state that the collective farms entered the first post-war five-year plan significantly weakened, with a drastically reduced labor force, with an undermined material and technical base. Nevertheless, memoirists note that material deprivation during this period was consciously perceived as temporarily inevitable, as a consequence of the war.

The people who came out of the war had to clearly imagine ambitious goals, for the sake of 
which it was worth working, possible to overcome everything. Thus, a kind of symbol of the future appeared in the public consciousness "the great construction sites of communism" the Chardzhou-Kungrad railway, the MainTurkmenCanal (KarakumCanal).Observing life in the country in the first post-war years, the memoirists noted that a firm belief of the population that everything is rapidly changing for the better served as a worthy compensation for difficulties and hardships. Over time, it will become obvious that the idea of building the Main Turkmen Canal along the ancient channels of the Uzboy of the Amu Darya River, formulated as a practical goal, ran far ahead, turned out to be unrealized. But this idea nevertheless played its mobilizing role in the first post-war years. The desire to participate in the "building of communism", which was considered the Chardzhou-Kungrad railway and the MainTurkmenCanal, awakened the labor activity and creative thought of the population of Karakalpakstan.On the wave of enthusiasm among collective farmers, traditions and labor initiatives, born in antiquity ("Hashar"), the prewar and war years, continued to develop and spread. Contemporaries more often recalled the end of the 40s, when the Stakhanovites and shock workers were the most respected people.
In the postwar years, much attention was paid to the development of road transport and the asphalting of dirt roads. The main highway Khodjeyli - Pristan - Nukus - Khalkabad Chimbay with a length of $164 \mathrm{~km}$ was built. Nevertheless, the absence of railway lines (the cheapest after waterways) in Karakalpakstan caused enormous difficulties in the development of the national economy.

On the agenda was the question of building a railway from the city of Chardzhou through Khorezm and Karakalpakstan to the city of Beineu - Kazakhstan. The first secretary of the regional party committee P. Seitov took advantage of the favorable moment - the adoption of the project of the century - of the MainTurkmenCanal raised the question to the first secretary of the Central Committee of the Communist Party of Uzbekistan UsmanYusupov about the construction of a railway in Karakalpakstan.

"I asked the Central Committee of the Communist Party of Uzbekistan to resolve the issue of building a railway for Karakalpakstan," PirzhanSeitov recalled in those years. - First Secretary of the Central Committee of the Communist Party of Ukraine UsmanYusupov took responsibility for the construction of the Chardzhou-Kungrad railway line. The 
participation of 35 thousand people from Karakalpakstan in this construction was envisaged.These 35 thousand people were gathered in the districts. Due to lack of transport, many builders went on foot to Dargan-Ata. MatekeJumanazarov (Chairman of the Presidium of the Supreme Soviet of the KKASSR), members of NauryzDzhapakov (chairman of the Council of People's Commissars of the KKASSR) and G.I.Skorobogatov (second secretary of the Karakalpak regional committee of the WUCP (b)) were appointed as the chief of staff of the site allocated to Karakalpakstan.All agricultural and other work I had to supervise myself" [5].

UsmanYusupov wanted to strengthen the friendship of the peoples inhabiting Uzbekistan, to bring the distant and close regions of the republic closer together. One of his main dreams was to connect Khorezm and Karakalpakstan by rail with Tashkent and other regions. $\mathrm{He}$ understood the importance of connecting Central Asia through the Ustyurt plateau with the help of a railway with Europe.On this basis, the construction of the Chardzhou-Kungrad railway was started in 1947. In the summer of the same year, more than 100 thousand people were mobilized for construction, in 45 days with the help of workers more than 5 million cubic meters of land was raised under the rails in the
Chardzhou- Khazarasp.This construction was one of the largest in Uzbekistan, which played a radical turning point in the socio-economic development of Karakalpakstan and Khorezm [2,p.20].

The merit of UsmanYusupov, who brought the railway to Karakalpakstan, Khorezm and Tashauz regions, is invaluable. This is a fatherly concern, a thought about the future of the people and their material security.

The years of restoration of the national economy after the Second World War, only now, are becoming the object of deep study. However, in historiography, the question of the fate of the political prisoners of the Takhiatash camp, of the participation of the population of the republic in the construction of the MainTurkmenCanal remains undeveloped. We think that the memories of living participants in these events will provide a lot of information for reflection.

The head of Karakalpakstan in the late 40s and early 50s, PirzhanSeitov, was a very intelligent, modest person. "His ability to dress, to behave in public, aroused the love and admiration of those around him," Kamalov recalls. "He was a very neat, very strict and charming person.He never indulged in idleness, could not stand alcohol, never hearsay, was a highly cultured and highly 
CURRENT RESEARCH JOURNAL OF HISTORY 2(5): 59-65, May 2021

DOI: https://doi.org/10.37547/history-crjh-02-05-15

ISSN 2767-472X

(C)2021 Master Journals

Crossref doi 8 Google

Accepted 25th May, 2021 \& Published 31 th May, 2021

moral person. I never smoked, I couldn't even stand tobacco smoke. Of course, all these good qualities of PirzhanSeitov had a positive impact on all of us, his many students" [2,p.20].

Memories of N. Mukhitdinov, K. Kamalov, A. Kunnazarov are of great importance for rethinking the post-war period and the period of "great construction projects" - the ChardzhouKungrad railway line, the MainTurkmenCanal.

In the second half of 1954, the Chairman of the Government of Karakalpakstan P. Seitov together with the Chairman of the Government of Uzbekistan N. Mukhitdinov submitted Notes on an important, key issue affecting the direct interests of the inhabitants of the region and the development of agriculture for consideration by the Central Committee of the CC CPSU and the Council of Ministers of the USSR."Having prepared the necessary documentary justifications and calculations," N. Mukhitdinov recalls this process of "begging" the Center for subsidies, -we made detailed proposals, in which we provided for requests: to increase the basic weighted average procurement price per ton of raw cotton of domestic varieties for all collective farms from 2150 rubles up to 3100 rubles and fine-fiber varieties from 3660 rubles up to 6150 rubles; to stop differentiating payments of premiums-allowances to collective farms within the plan; for each ton of raw cotton handed over by collective farms in excess of the contracting plan, to pay a premium in the amount of $100 \%$ to the main procurement price; in order to encourage collective farms to pay bonuses for achieving high yields of raw cotton; to terminate, starting from January 1, 1955, the effect of the resolution of the Council of Ministers of the USSR of April 29, 1949 No. 1720 on the introduction of monetary payment for water used for irrigation, the needs of enterprises and other economic needs; to grant cotton-growing collective farms the right, at their discretion, to set the amount of contributions to the indivisible funds within the range of $10-15 \%$ of monetary income;to allow collective farms to pay for the workdays spent on irrigation construction, the construction of livestock and other premises, the establishment of orchards, vineyards, mulberry plantations and other perennial plantations at the expense of indivisible funds; to write off from the cottongrowing collective farms the arrears in contributions to the indivisible funds, formed as of January 1, 1955; to introduce for the collective farms of the republics of Central Asia and the Transcaucasus for a period of 3 years the selling prices for mineral fertilizers, which exceed by $50 \%$ the current prices for collective farms of the RSFSR, BSSR, and the Ukrainian SSR; to reduce 
the rate of payment in kind for MTS tractor work within the range of $15-20 \%$ and to establish material responsibility of MTS for the cotton yield on collective farms; to provide additional benefits for collective farms developing new irrigated lands for sowing cotton" [4,p. 122-123].

These government documents came out at the end of 1955 with entry into force on January 1, 1956. The past year and a half turned out to be for N. Mukhitdinov, P. Seitov and other leaders literally "walking through torments". They made "shuttle flights" between Tashkent and Moscow, knocked down the doorsteps of ministers and senior officials of the central office. It is important to emphasize that this great concern for cotton growers had a positive impact on the rise of cotton growing, was well received in all cotton-growing collective farms, state farms, districts and regions, as evidenced by the significant development of cotton growing and other branches of irrigated agriculture in 1956.

Memoirs of contemporaries are valuable sources for characterizing the leaders of the second half of the twentieth century in our region. The actions of the new leader of Karakalpakstan, NosirMakhmudov, were accompanied by adventurism, which Kamalov recalls with bitterness: he introduced the practice of shallow sowing of cotton seeds. The collective farms of the northern regions of the republic were disbanded, and state farms were created together. As a result, out of 475 collective farms, only 38 remained; on the basis of the remaining 437 collective farms, more than 20 large state farms were created. For example, on the scale of one Kegeilinsky region, one state farm "Kegeili" was created (director - A.S. Gulyants). He could not, with all his desire, thoroughly study the state of the state farm economy due to the large territory [2,p.64].

Instead of eleven districts, there were three districts. It took 15 days for the head of the enlarged region to visit their farms and get acquainted with them. The reduction of experienced business executives who worked in managerial positions caused great damage to the national economy. Even sending an authorized republican asset to farms for a year did not help. Scientists were forced to write their doctoral dissertations without interrupting their duties as representatives of the republican activists in the fields of collective farms, as Academician S.K. Kamalov wrote about [3].Soontheyhadtoabandonthisideaof consolidation.

The division of the party organs into industrial and agricultural, the system of economic councils, - states the memoirist K. Kamalov, - was 
CURRENT RESEARCH JOURNAL OF HISTORY 2(5): 59-65, May 2021

DOI: https://doi.org/10.37547/history-crjh-02-05-15

ISSN 2767-472X

(C)2021 Master Journals

Crossref doi 81 Google

Accepted 25th May, 2021 \& Published 31 th May, 2021

completely incomprehensible and difficult to fit into the concept of "improving management." On the scale of Karakalpakstan, regional committees for industry and agriculture were created, and in the regions of the republic there were positions of the head of agricultural departments. Party bosses of the districts moved to second positions in the conditions of the agrarian republic. Thus, the party and economic leaders of the districts: Turtkul - K. Nurimbetov and M. Rozumbetov; Amudarya - F. Vasigov and R. Japakov; Khodjeilinsky - D. Ozhyraev and V. Dontsov; Kegeilinsky - P. Khalmuratov and T. Naurizbaev; Chimbaysky - K. Abdreimov and H. Mazhitov had to solve the question: who is the boss in the area? This lasted only two years, but nevertheless caused enormous damage to the national economy.

The vicissitudes of the convocation of the first congress of the intelligence part of Uzbekistan and Karakalpakstan on October 10-13, 1956 in Tashkent are sufficiently reflected in the memoirs of N. Mukhitdinov, who initiated the organization of this event. 1,200 delegates attended the convention. N.Mukhitdinovmade a report on the process of rehabilitation of the repressed. When he talked about who organized the whole case of repression, how they glued labels to this or that intellectual, leader, not only individuals, but entire groups, there was a violent reaction in the forum hall. In total, about 40 thousand people, living and dead, were rehabilitated in Uzbekistan and Karakalpakstan.

Construction of modern highways on both banks of the Amu Darya: Gazli - Urgench - Takhiatash Kungrad - Muynak (about 450 km), Dul-Dul Turtkul - Beruni - Nukus - Kazakhdarya (about $330 \mathrm{~km}$ ) and the Tashkent - Aral Sea in the 70s of the XX century meant breaking the deadlock and connecting into a single transport system of Uzbekistan.

The middle of the $60 \mathrm{~s}$ is characterized by increased attention to the development of rice growing in Karakalpakstan. If in 196525.7 thousand tons of rice were grown, in 1983 this figure reached 332.3 thousand tons. In 1980, there were 17 rice-growing state farms in Karakalpakstan equipped with modern agricultural machinery. If in 1970 the gross harvest of rice was 59.1 thousand tons, then in 1980 it reached 296.5 thousand tons.

From the point of view of source study and historiographic value, portraits of prominent statesmen of Uzbekistan - UsmanYusupov, SharafRashidov and Islam Karimov created by K. Kamalov are of great importance. For the sake of fairness, we note that this completes the touches 
to the political portrait of these figures, which cannot be found in the official history. For example, the facts of receiving a reprimand from the Politburo of the CPSU Central Committee by UsmanYusupov in 1947, when he personally headed the construction of the ChardzhouKungrad railway. K. Kamalov pays special attention to the personality of SharafRashidov, an outstanding figure of Uzbekistan in the 60-80s of the XX century. His style of state leadership, his role in training personnel for Karakalpakstan, his tireless work to protect the interests of the Uzbek and Karakalpak peoples in the conditions of totalitarian statehood, in the regime of subordination to the governors of the Center are well covered in his memoirs. The sections of $\mathrm{K}$. Kamalov's memoirs about SharafRashidov are important, for "while rehabilitating the name of SharafRashidov today, we must see in this matter a modest but organic part of the big work to clear the name of the Uzbek people" [1,p.93].

Continuing to create portraits of statesmen, $\mathrm{K}$. Kamalov highlighted PirzhanSeitov, MatekeZhumanazarov, NauryzZhapakov, their role in the development of the national statehood of the Karakalpak people in the pre-war years, during the Second World War, during the restoration of the national economy. These figures did everything to exalt the good name of the Karakalpak people, to show the whole world its wonderful features. The way of thinking and deeds of these outstanding figures, their harmony was for K. Kamalov and his associates a guide in work and life. At the same time, $\mathrm{K}$. Kamalov's memoirs also reflected the times of the leadership of such figures of Karakalpakstan as OrziMakhmudov, NosirMakhmudov, who left a kind of trace in the people's memory.

\section{REFERENCES}

1. Karimov I.A. The fiery heart of the son of the people. Speech at the celebrations dedicated to the 75th anniversary of SharafRashidov. November 1992 // Karimov I.A. Uzbekistan: national independence, economy, politics, ideology. T.1. Tashkent. 1996.-P.93.

2. Kamalov K. At peoples' serve. Memoirs... p. 20.

3. Kamalov S.K. Thoughts about represent// Council of Karakalpakstan, 1990, October 27

4. Mukhitdinov N. Years spent in the Kremlin. Tashkent. 1994.- p.44.

5. Seitov P. On a big road. Memoirs // Council of Karakalpakstan, 1984, 15 November 